\title{
INDUSTRIAL WELFARE AND LABOUR REGULATION IN BRITAIN AT THE TIME OF THE FIRST WORLD WAR
}

War, it has been asserted, stimulates the development of public welfare. Increased physical and social mobility, fostered by wartime conditions, exposes social inequalities and injustices, gives rise to demands for redress and thereby encourages government to introduce social reforms. This argument implies that, in order to maintain national solidarity in the face of a common enemy, central government becomes more sensitive to external political demands and thereby more - rather than less - responsive to democratic pressure. ${ }^{1}$ Certainly, during the First World War, it is possible to see increased state involvement in a number of initiatives designed to effect social improvement. This article examines one of them. It aims to analyse the role of central government in stimulating the development of private industrial welfare in Britain during this period. However, as will be shown below, the growth of industrial welfare - especially in the latter part of the war - was not designed to further industrial democracy. Rather, the form it took implicitly placed new constraints on the right of organised labour to demand improvements in working conditions. Although outwardly the industrial welfare movement sponsored by government seemed to win benefits for the working man, the use of scientific method to legitimate these improvements did not imply an increase in the power of organised labour to determine working conditions.

The study of state involvement in social policy in the early twentieth century has focussed on the appearance of new legislation; this defines the responsibilities being given to specific agencies, and entails direct expenditure of public money. It would be a mistake to assume that all developments in official welfare policy can be traced through the clauses of Acts of Parliament. The proliferation of statutory instruments during the twentieth century has allowed government departments to initiate new

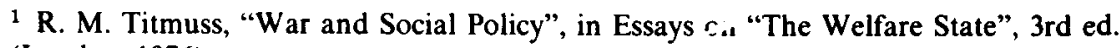
(London, 1976). 
welfare provision without having to draft fresh legislation. This was certainly the case during the First World War, when the Defence of the Realm and the Munitions of War Acts gave central government virtual carte blanche in developing its controls over industry and the industrial labourforce. In some respects this study lies in the penumbra of official social policy - being neither the subject of public debate nor, except indirectly, of statutory law.

Studies of social policy in the decade before the war have shown that welfare provision was directly linked to the need to foster industrial growth, thereby ensuring national prosperity. ${ }^{2}$ In other words, government ceased to be solely concerned with mitigating the social consequences of widespread poverty, and became involved with the organisation and regulation of the labour market. If patterns of employment could be rationalised, natural resources fully utilised, if those out of work could be retrained in other skills or resettled in other areas, if workers could be forced to save against the possibility of disease or unemployment, then potential sources and causes of poverty could be eliminated, the British economy would prosper and the British nation could maintain its dominant position in the world. Such attitudes provided a framework within which diverse areas of state activity fitted. Both reports of the Royal Commission on the Poor Laws ${ }^{3}$ illustrate this point. The problem of poverty was linked to the problem of employment; on this basis, recommendations could be made about such apparently diverse matters as public health, technical education and the central organisation of labour.

During the war the problems of poverty and destitution diminished, but, if anything, the need to control the labour market became more urgent. Rationalisation of manpower resources and the promotion of indu.rial productivity had initially been desirable for the sake of general prosperity. Now both were considered vital for national survival. As other studies have shown, new statutory restrictions imposed on the industrial labour-force during the war were widely resented, ${ }^{4}$ industrial unrest was just as disruptive of efficient production as the maldistribution of manpower. In this way

2 A guide to the literature is provided in J. R. Hay, The Origins of the Liberal Welfare Reforms (London, 1975).

3 See K. Woodroofe, "The Royal Commission on the Poor Laws, 1905-09", in: International Review of Social History, XXII (1977), especially pp. 151-55.

4 Such studies include B. Pribićević, The First Shop Stewards' Movement and Workers' Control (Oxford, 1959); J. Hinton, The First Shop Stewards' Movement (London, 1973); C. J. Wrigley, Lloyd George and the Labour Movement (London, 1976); R. Harrison, "The War Emergency Workers' National Committee", in Essays in Labour History 1886-1923, ed. by A. Briggs and J. Saville (London, 1971); R. J. Q. Adams, Arms and the Wizard: Lloyd George and the Ministry of Munitions (Harvard, 1978). 
state welfare policy aimed to serve two goals - to guarantee the effective deployment and use of manpower, and to reduce the risk of disputes and strikes brought about by changes in working practices - notably in the displacement of craft and skilled sectors. The use of state welfare schemes as agencies for the management of labour on a national scale had already been initiated under the 1911 National Insurance Act, when central government had taken tentative steps towards the elimination of waste of labour in some industries - notably the casual trades. ${ }^{5}$ Not surprisingly, welfare policy continued to play a major role in developing techniques in labour management, in response both to the crisis in supply and demand and to the ensuing outbreaks of industrial unrest which threatened to disrupt the war effort.

This marriage of welfare and management was not the simple consequence of government initiative, but represented - in some respects state endorsement of methods used by employers in a variety of industries before the First World War. Profit-sharing and co-partnership schemes had proved useful antidotes to the attractions of union organisation. Industrial welfare helped overcome resistance to technological innovations and, more generally, increased loyalty to the firm. ${ }^{6}$ In larger units of production, a similar approach justified systems designed to restore the "personal touch" to a shop-floor increasingly remote from management; the provision of "overlookers" and superintendents in factories employing large numbers of women workers can be seen as an example of this trend. ${ }^{7}$ Such tactics designed to foster identification with the firm tended to be introduced in response to the socialist challenge for increased workers' control. Industrial welfare made concessions without damaging the ultimate authority of the employer to manage his business as he saw fit. ${ }^{8}$ . ot surprisingly, similar motivations encouraged the expansion of private welfare systems during the First World War, especially in the face of growing rank-and-file militancy in the engineering and shipbuilding trades. The interest of government in the outcome of the dilution struggle gave added impetus to official intervention in this area. Although direct state involvement did not survive long after the Armistice, tacit approval and financial encouragement continued to be given to employers who

5 N. Whiteside, "Welfare Insurance and Casual Labour", in: Economic History Review, Second Series, XXXII (1979).

6 J. Melling, "Industrial Strife and Business Welfare Philosophy", in: Business History, XXI (1979).

7 A. Briggs, Social Thought and Social Action: A Study of the Work of Seebohm Rowntree 1871-1954 (London, 1961), p. 103. This describes the use of "social helpers" in the Rowntree cocoa works at York.

${ }^{8}$ Melling, "Industrial Strife and Business Welfare Philosophy", loc. cit., p. 176. 
utilised official recommendations on welfare systems to suit their own circumstances.

This study does not pretend to be a detailed assessment of improvements in working conditions brought about by wartime expansion of government policy. It has relied on the research of others to help establish the overall picture; Marian Kozak's work on welfare provision among women munition workers has proved extremely useful. ${ }^{9}$ Joe Melling's research into the ways in which industrial welfare was incorporated into management strategies of British employers during this period has also helped shape my arguments and has been generally informative. ${ }^{10}$ Rather, my paper will identify principles underpinning all aspects of official encouragement of industrial welfare. It will use both official justifications and the response of both sides of industry to this initiative for this purpose. It is necessary to re-assess expansion of social policy during the war in order to correct the common assumption that is found in too many texts: that wartime initiatives in the area of welfare are based solely on government's paternalist assumptions about the needs of the nation. In the First World War, at least, this explanation is quite inadequate.

In August 1914, the well-being of the industrial workforce was in part determined by statute, in part by custom and agreement between employers and unions (where the latter were recognised). The outbreak of war, however, destroyed both public and private constraints on industry's use of labour. In March 1915, Lloyd George negotiated an agreement with most union leaders to suspend workshop practices for the duration of hostilities. ${ }^{11}$ The following July, limitations on the hours of work as laid down by the Factory Acts also went into abeyance. ${ }^{12}$ These changes - coupled with new statutory restrictions on the working man's right to sell his labour altered the context within which the formation of welfare policy could be considered. This was especially true of those industries covered by the

9 M. Kozak, "Women Munition Workers in the First World War" (unpublished Ph. D. thesis Hull, 1976).

10 Melling, "Industrial Strife and Business Welfare Philosophy"; also id., "NonCommissioned Officers': British employers and their supervisory workers", in: Social History, V (1980).

11 W. H. Beveridge, Power and Influence (London, 1953), pp. 123-25; J. Harris, William Beveridge (Oxford, 1977), pp. 204-05.

12 From that date, hours of work were nominally limited to $671 \frac{1}{2}$ hours per week; the prevalence of overtime and widespread use of shift systems made such regulations inoperable. 
Munitions of War Acts. The disappearance of formal and informal controls in a wide area of private industrial management opened the gates for potential exploitation and abuse. This posed a threat to continuing good industrial relations and the smooth running of the British war economy. Furthermore, the growing shortage of manpower encouraged the recruitment of sections of the population into industrial employment who were not used to factory life. Somehow, increasing numbers of women and juvenile workers had to be intregrated in to the workforce. Not only did the new recruits have to adapt quickly to a much more disciplined existence, but the existing workforce had to be reconciled to their appearance. Women and boy workers were commonly introduced into factories as part of the process of dilution in skilled sectors, which did little to guarantee their popularity.

The final major change which altered the government's perspective on matters of industrial welfare was the fact that the war caused the distinction between state and employers to blur considerably. Under the Defence of the Realm Act and the Munitions of War Act, the government was empowered to take over land, buildings, factories and manufacturing plant for essential war purposes, could commandeer production and supervise management. Such powers became vested in the Ministry of Munitions after June 1915. This department grew enormously during the course of the war. It not only supervised the invention, testing and manufacture of all armaments, explosives and munitions; it also undertook a massive amount of semi-associated work concerning chemical and engine development, requisitioning trucks and laying railways. It bought, sold and stored vast quantities of materials at home and abroad. It built not only factories to make munitions, but also houses and hostels for workers employed in them; such work included laying roads, providing drainage and power supply. This involved the Ministry directly in the regulation and apportionment of civilian manpower resources and thereby in the livelihood of literally millions of industrial workers. By the end of the war, more than $3,400,000$ were employed in munitions work, and about $2,250,000$ in controlled establishments. ${ }^{13}$ In these factories, the Ministry determined hours and regulations governing work, as well as resolving questions concerning wages. To all intents and purposes, the Ministry had become an employer; it was the practical experience it gained in carrying out its obligations in this capacity, that was to lead it into the development and administration of industrial welfare during the war.

${ }^{13}$ G. R. Rubin, "The Origins of Industrial Tribunals", in: Industrial Law Journal, VI (1977), p. 162. 
These main factors - the suspension of formal constraints on management, the introduction of an inexperienced labour-force, together with the industrial unrest that could result from dilution, and the emergence of the Ministry of Munitions as a major employer in its own right - all provided the context within which welfare policy developed. The Ministry's involvement with the supply, distribution and efficient use of manpower gave it a direct interest in existing policies affecting labour management. Accordingly, in the spring of 1915, the cream of the Board of Trade Labour Department, including Llewellyn Smith, Beveridge, Rey and Wolff were transferred to the new Ministry in order to bring their pre-war experience to bear on the problems of labour regulation. The following January, a new division was created to deal specifically with industrial welfare and Seebohm Rowntree was recruited, direct from his position as labour manager at his father's cocoa factory at York, to be its director. ${ }^{14}$

The primary aim of the Ministry was the production and distribution of munitions. Its obligation to both the taxpayer and the state was to ensure that this was done as efficiently as possible. This meant keeping costs low while guaranteeing that the needs of the armed forces were met. The concern of government did not stop at the simple allocation of the requisite numbers of men and women to keep the factories going. Each worker had to become a competent productive unit. The health and welfare of munition workers became a cause for official concern. Therefore, the development of social welfare in the context of total mobilisation became inextricably entangled with the questions of productivity, industrial relations and the general needs of the war effort. Costs of retraining had led to restrictions being placed on the mobility of certain categories of male workers; ${ }^{15}$ the rest of the labour-force - especially women and juveniles had to be encouraged to stick to their jobs in a similar fashion. The suspension of the Factory Acts - ostensibly to accommodate new output targets - led to further investigations in to the impact of industrial fatigue on work performance, the impact of unhygienic work conditions, overcrowded housing and general bad diet on the health and the working capabilities of factory hands. In undertaking this wide range of activities covering housing, health, diet, recreation, education and training - the Ministry made little secret of its real purpose: the promotion of maximum industrial output. This priority was written into the terms of reference of

14 Beveridge, Power and Influence, op. cit., pp. 124, 128-29. Rowntree's work as director of the Welfare Department is described in Briggs, Social Thought and Social Action, op. cit., ch. V.

15 The operation of the leaving-certificate system is described in Hinton, The First Shop Stewards' Movement, op. cit., pp. 35-37. 
the Health of Munition Workers' Committee, created by Lloyd George in September 1915:

To consider and advise on questions of industrial fatigue, hours of labour, and other matters affecting the personal health and physical efficiency of workers in munitions factories and workshops. ${ }^{16}$

Or, as the committee itself put it - in more succinct terms -, "without health there is no energy, without energy there is no output."17

It was the work of Rowntree's Welfare Department to supervise the implementation of the committee's recommendations on the factory floor. To start with, however, health of munition workers was catered for on absolutely basic terms. In the munitions factories, men and women were handling materials designed to kill the enemy; it was desirable that they should do so without mortally injuring themselves or their workmates. TNT and poisonous gas presented obvious hazards. The Treasury raised little objection to extending industrial compensation to cover those suffering from their side effects - especially when informed that to refuse to accept responsibility might affect productivity. ${ }^{18}$ A Ministry of Munitions official put this argument to the Treasury in August 1916:

Mr. Montague fears that, unless measures are taken [...] to meet this difficulty, serious interference with output may arise as if the operatives become frightened at the number of diseases and deaths of their colleagues, greater difficulty than ever will be experienced in procuring labour. ${ }^{19}$

The Treasury response was generous, and its treatment of poisoned munitions workers got even more beneficent as the war went on. The introduction of sick pay at $£ 1$ a week in the summer of 1916 was supplemented by a per capita grant to cover the hospitalisation of all munition workers suffering from toxic jaundice in March 1917. A special-diet allowance was granted the following June. ${ }^{20}$ The response was motivated less by a rising percentage of workers suffering from TNT poisoning than

${ }^{16}$ Health of Munition Workers ' Committee, Final Report [Cd 9065] (1918), p. 3. This committee included representatives from the Board of Education, Factory Inspectorate and the Medical Research Committee as well as the Ministry of Munitions.

${ }^{17}$ Health of Munition Workers' Committee, Conclusions (December 1918), p. 3, § III (vii). Confidential print in the Ministry of Reconstruction Papers 1/805, Public Record Office.

18 Correspondence on compensation for the victims of various industrial diseases is in Treasury Papers $1 / 12059 / 21319 / 1917$, PRO, whence is derived information in this paragraph.

${ }_{19}$ Ibid., 24 August 1916.

${ }^{20}$ Meta Zimmeck, editor at the Public Record Office, has examined compensation case-files, and informs me that, in practice, the implementation of policy was less generous than these concessions seem to suggest. 
its potential impact on recruitment at a time when manpower sources were diminishing. This was to prove a common pattern.

Through this concern with the health of munition workers, the Ministry introduced doctors, medical personnel and first-aid units - initially into controlled factories, subsequently, by order, into all metal working industries. ${ }^{21}$ Investigations into diet led to the provision of factory canteens, in co-operation with the Central Control Board (Liquor Traffic). ${ }^{22}$ The HMWC undertook extensive research into all causes of wastage of manpower and made recommendations on hours of work, the need for breaks, pauses and holidays, the comparative productivity of overtime, the maintenance of factory discipline and the provision of a myriad of amenities, ranging from cloakrooms to overalls and seating arrangements in the workplace. Investigations were also carried out into the effects of industrial training on productivity and the comparative efficiency of different types of work incentive. ${ }^{23}$

Persuading employers to conform to the committee's findings was another problem. All factories under the control of the Ministry were liable to visits from the welfare inspectorate, which drew attention to the HMWC's published reports and reminded employers that the cost of any improvements made could be set off against excess-profits tax. Rowntree also initiated a scheme to allow employers to meet the salary of welfare supervisors in the same way. ${ }^{24}$ Such officials were appointed in all national factories and the Ministry's Appointments Branch maintained a list of suitable candidates who were available for employment in independent industrial concerns. The chief tasks of the welfare supervisor were to ensure that medical standards were met, to supervise the selection and training of personnel, to encourage their employer to conform to approved working conditions and to deal with disciplinary problems. They were introduced to cater for the needs of the new industrial recruits - women and juveniles. ${ }^{25}$ Their chief objective was clearly to stabilise and discipline this section of the workforce, whose movements were not subject to statutory regulation. Constant retraining of new recruits was expensive and wasteful. Women

21 Under the Police, Factories, etc. (Miscellaneous Provisions) Act, 1916.

22 For further detail, see M. E. Rose, "The Success of Social Reform? The Central Control Board (Liquor Traffic) 1915-21", in: War and Society, ed. by M. R. D. Foot (London, 1973).

${ }_{23}$ The HMWC eventually produced twenty published reports, besides its Final Report, op. cit. Documentation on the work of the committee is to be found in Ministry of Munitions Papers 4/6338, PRO.

24 History of the Ministry of Munitions, V (London, 1920), P III, pp. 21-22.

25 A copy of the Handbook for Welfare Supervisors and Apprentice Masters is in the Ministry of Munitions Papers 4/6338. 
workers needed special attention, partly because of their role as mothers; during the war maternal and infant welfare was becoming a widespread cause for concern. ${ }^{26}$ Hence these reasons were also brought forward as justification for their special treatment:

the physiological disabilities of women must be taken fully into account, not merely for the reason that the overstrain of industrial work immediately before or after childbirth involves the risk of grave injury to women and child alike, but because the strain of long standing or continuous overwork in girlhood and later [...] may have far reaching effects on the birth-rate and the degeneration of the race. ${ }^{27}$

By the end of the war about 275 boys' supervisors and 550 women's supervisors were working in controlled establishments; a further 450 women's supervisors had been appointed in private firms outside the direct control of the government. ${ }^{28}$

The Ministry of Munitions strove to become a model employer, using example and education to persuade those employers it was not empowered to direct, to conform to the directions of the HMWC. As the war continued, the manpower problem increased and concern over the dilutees expanded; the department responded by widening its sphere of interest and tightening up on its procedures. In the former instance, although the provision of houses was the responsibility of the Munitions Works Board, ${ }^{29}$ hostels and temporary accommodation, the food, transport and recreation facilities provided for women workers, all came under the supervision of the welfare inspectorate in the course of 1917. As far as relations between the department and employers were concerned, Rowntree's preference for persuading employers to implement welfare recommendations - by demonstrating their beneficial effect on productivity and profits - rapidly became outdated. Such methods did not fit well with the scientific rationale underpinning the work of the HMWC; Rowntree became involved in heated arguments with the committee's chairman, Sir George Newman, as well as with other senior civil servants. His advocacy of works councils, to allow labour a limited say in determining industrial conditions, did nothing

${ }^{26}$ Infant and maternal welfare excited much official concern during the war. See J. M. Winter, "The Effects of the First World War on Civilian Health in Britain", in: Economic History Review, Second Series, XXX (1977), and Anna Davin, "Imperialism and Motherhood", in: History Workshop, No 5 (1978).

27 Medical Research Committee, Memorandum on Hours of Work in Relation to Output and Health (February 1918), p. 5, Ministry of Reconstruction Papers 1/803.

28 History of the Ministry of Munitions, loc. cit., pp. 37, 42.

29 By the end of the war, the Ministry had received Treasury sanction for the building of 152 hostel blocks and over 8000 houses and cottages (figures for August 1919), see Ministry of Munitions Papers 4/6772. 
to endear him either to the scientific managers or those employers who had no desire to increase union influence in any way at all. ${ }^{30} \mathrm{His}$ successor, $\mathrm{Dr}$ Collis - a medical inspector from the Home Office - was more in sympathy with prevailing trends and made greater use of available legislation to enforce minimum standards ${ }^{31}$ Growing use of compulsion was to play no small part in alienating many employers who resented this official imposition of industrial philanthropy. Nonetheless the work of Collis and his team continued to clarify and publicise the hitherto unspoken assumption - that welfare was a vital component of economic efficiency. Demonstrations to this effect were provided by the Dilution Bulletin, which cited instances of firms experiencing a rise in output as a result of providing better diet, rest rooms and medical facilities for the workforce at the factory itself. These activities were justified by the wartime emergency, but accelerated the development of techniques in labour management which had a broader importance.

The History of the Ministry of Munitions stresses the altruistic aspect of the Welfare and Health Department's work, especially in relation to newly recruited female labour. Even so, it concedes that the department extended the elementary principles of the Shaftesbury Acts to foster a world in which the worker's ties to his firm assumed Orwellian proportions.

The firm could thus absorb the seven ages of life of a workman, who might [...] attend the factory creche as a baby, play in its recreation ground as a child, join its work school and scout troup as a boy, belong to its football club and social institute as a youth, bring up his family in one of its cottages, receive medical treatment during illness or accident in later life with financial help from the management or the works sick fund and end his days as a pensioner of the firm or the works benefit society. ${ }^{32}$

Such a vision of the future welded the whole lifestyle of the individual to his economic role in society; even the official historian was moved to question whether this was desirable. The fact that these extensions in welfare were rooted in the firm or factory - not in the state or even the local community - increased the reliance of the worker on his employer.

The official history interprets these developments as a demonstration of state socialism. ${ }^{33}$ Such an analysis is far from satisfactory. The Ministry of

30 Briggs, Social Thought and Social Action, pp. 120-26.

31 Rowntree's successor, Dr Collis, had been medical advisor to the Home Office factory inspectorate. Orders concerning heating, protective clothing, canteens, cloakrooms, etc., were issued under the Act cited in note 21. The expansion of the department's responsibilities caused it to change its name to the Welfare and Health Department early in 1917.

32 History of the Ministry of Munitions, loc. cit., p. 169.

33 Ibid, pp. 176-77. 
Munitions was a business concern, albeit not a very efficient one. ${ }^{34}$ As a would-be model employer, it demonstrated that the welfare provisions it was trying to foster had long-term implications for future labour management - whether operated by government or by private enterprise. These provisions quite obviously derive much from the principles of scientific management which had been expounded by Taylor and his followers in the United States before the war. Both the American theories and the ideas of Dr Collis and his team centred on the need to maximise industrial productivity and minimise costs, a process which implied increased control of management over all sectors of the industrial process. Official intervention in Britain along these lines had been started during the wartime emergency. Dilution had broken down barriers to management control previously imposed by highly organised skilled workmen. The way was now open for the new techniques to be adapted for peacetime purposes. Scientific investigation would determine the parameters of individual effort; employers could use official recommendations to modify their systems of management. Dr Collis wrote in 1919:

Indiscriminate and ill directed efforts [to produce welfare schemes] are apt to drift into schemes of expensive philanthropy, while well judged plans are a powerful aid to economic efficiency. [...]

We can no longer afford to leave to the ill directed demands of labour the determination of the hours of work [...] and the correct, scientific interpolation of rest pauses; these matters must be determined by careful study and research if the demands of labour are not to run far beyond the possibilities of economic efficiency. ${ }^{35}$

No one would accuse the good doctor of socialist sentiments here.

By the time of the Armistice, pressure to rationalise the manufacturing process had mounted considerably. Philanthropy had given way to scientific management. The experience of the war was clearly reflected in the Ministry of Reconstruction's published pamphlets, ${ }^{36}$ two of which laid down guidelines for government and employers designed to guarantee

34 The Ministry's handling of contracts and keeping of accounts was chaotic and, in spite of persistent pressure to rationalise its procedure, little improvement was made by the end of the war. The extent of this mismanagement of public funds was first revealed in the Comptroller and Auditor General's Appropriation Account for 1916-17, Treasury Papers 172/831.

${ }^{35}$ Collis, Memorandum to Mr Piggott, "Should the Ministry of Supply have a Welfare and Health Department?" (January 1919), pp. 1-2, Ministry of Munitions Papers 4/6338. After the Armistice, the future of the Ministry as a peacetime Ministry of Supply was under serious consideration.

${ }^{36}$ These included one on techniques in scientific management, Ministry of Reconstruction Papers $1 / 882$, and one on the employment and training of juveniles, Ministry of Reconstruction Papers 1/880. 
peacetime prosperity. As far as the education and training of juveniles was concerned, the experience of the Ministry of Munitions had had a clear impact on proposals for the future. The wartime collapse of the apprenticeship system, coupled with widespread and indiscriminate recruitment of boy labour in well-paid dead-end jobs, was recognised to have disrupted the process of instilling industrial discipline in the future labour-force. Boy labour had been widely in demand; as a result, the policy makers argued, sobriety, industry and good character had counted for less and less in the allocation of jobs. ${ }^{37}$ Steps had to be taken to counteract the possible consequences of this absence of traditional controls. Once again, the Director of Health and Welfare was quite explicit about the long-term justifications for the state broadening its interest in juvenile welfare.

The advantage to be gained by training the rising generation of workers on the right lines can hardly be exaggerated. They are more malleable and can be more easily influenced than are adults and more immediate results are therefore obtainable; while they will provide for the future a more capable and reasonable body of adult labour. ${ }^{38}$

Such conclusions reinforced pre-war emphasis on the desirability of making special provision for juvenile labour and had a marked impact on the planning of post-war education and training.

In general, the official promotion of industrial welfare was reminiscent of the recommendations found in the Poor Law Minority Report. Government was seen to have a primary responsibility in securing industrial efficiency and, thereby, national prosperity. Such central directives were tolerable in time of war. However, the unpopularity of government control over industry in general - including its interference in industrial welfare - made their continuation a very dubious proposition, once peace was restored.

\section{II}

Industrial-welfare policy developed in conjunction with the need to regulate the supply and distribution of labour. During the war, a number of vital commodities were in short supply and, under the circumstances, labour was a commodity much like any other. Careful management was needed to ensure its effective deployment. However, most official controls imposed on the labour market were clearly identifiable as such and were destined (or so the government had claimed) to be of temporary duration. The introduction of industrial welfare was altogether more insidious in its

37 See Handbook for Welfare Supervisors and Apprentice Masters, op. cit., p. 5.

38 Collis, Memorandum to Mr Piggott, p. 8. 
potential long-term effects. Legislation forcing certain employers to comply with government directives in this field was temporary. However, new techniques of labour management, under investigation during the war, could be adapted for peacetime purposes. In order to evaluate the impact of state promotion of industrial welfare on post-war planning and prorities, its development should be placed in a wider context.

Working-class attitudes towards this official intervention in industrial conditions present a very mixed picture. In the early stages of the war, it is clear that some sectors of the labour market were looking to central government for reform. Many women's organisations - including their Trade Union League, the National Federation on Women Workers, the Women's Co-operative Guild - petitioned for an increase in women factory inspectors, more protection for women working in dangerous trades, improved facilities for working mothers, as well as for equal pay. ${ }^{39}$ The TUC, by pressing consistently for the creation of a Ministry of Labour, evidently felt that workers' needs were best met by legislative reform..$^{40}$ The new department's main task would involve safeguarding health and safety at work, as well as providing the means for organised labour to be represented at the highest level. It was to give attention to issues like the standardisation of working hours and the raising of working conditions. The TUC noted with approval, in 1917, Home Office directives concerning the improvement of medical facilities in certain industries. ${ }^{41}$ In a very real sense, steps were being taken to make working conditions better, and this was popular.

On the other hand, as the war continued, any support for increased state intervention waned. Among the rank and file of munition workers, opposition to general wartime restrictions was apparent - as other studies have shown. Efforts to improve working conditions were being adapted by the Ministry of Munitions as an alternative to statutory coercion, in an effort to cope with working-class discontent. In the official historian's terms, the Ministry was accused of offering panem et circenses in the form of subsidised canteens and playing fields as an alternative to fundamental industrial reconstruction. ${ }^{42}$ It was no secret that the department saw its

${ }^{39}$ In this respect they echoed demands made before the war by the Home Office factory inspectorate. See, for example, the Lady Factory Inspector's Report in Annual Report of the Chief Factory Inspector for 1913 [Parliamentary Papers, 1914, XXIX]. Asa Briggs also mentions the early co-operation between Rowntree and the women's organiser Mary MacArthur, Social Thought and Social Action, p. 121.

40 See early chapters in R. Lowe, "The Demand for a Ministry of Labour, its Establishment and Initial Role" (unpublished Ph.D. thesis, London School of Economics, 1975).

41 TUC, Annual Report 1917, pp. 114-18.

42 History of the Ministry of Munitions, loc. cit., p. 169. 
welfare work as an integral part of its policy to secure efficiency and promote stability in the established industrial order; welfare was a tactical alternative to industrial discipline, but complementary to it.

Resentment against welfare developed among well-organised sectors of the labour market, and especially among women's organisations. This is not surprising. As Marion Kozak's research shows, the Ministry's welfare section made its greatest impact in industries recruiting large numbers of women workers. ${ }^{43}$ The appearance of welfare supervisors also excited hostility. Welfare supervision for boys was more strenuously resisted than for women, as was demonstrated on Clydeside, where the proposed introduction of welfare officers for juveniles was successfully and vociferously opposed by the labour-force. ${ }^{44}$ Further evidence of the unpopularity of welfare supervisors emerges in the reports made by the Commissioners for Industrial Unrest in 1917. These show that the new personnel were resented not only by union organisers and shop-stewards, but by the workers themselves. ${ }^{45}$ Reports from South Wales and Eastern England presented to the Ministry of Munitions in January 1918 provided further proof - if any were needed - of widespread suspicion of the supervisor's activities. $^{46}$ In 1918, the National Federation of Women Workers voted that the Welfare and Health Division be abolished; this reflected the tone of a similar debate by the Conference of Women's Organisations held the previous year. ${ }^{47}$ In the closing stages of the war, criticisms of the work of welfare officers and their staff became more blatant. By the time of the Armistice no support could be found in the union movement for continuing state intervention in this area ${ }^{48}$

Reasons for this resentment are not hard to find. Many union leaders and organisers - especially those involved in the recruitment of women pointed out that state encouragement of welfare work of this nature was in the main directed towards increasing productivity while apparently appeasing moderate demands for reform. It was also clear that welfare work could undermine the foundations of organised labour and, according to many of its practitioners, this was precisely what it was designed to do. It was no coincidence that the welfare activities of the Ministry expanded as

43 Kozak, "Women Munition Workers", op. cit., ch. VII.

44 See the autobiography of the Ministry's organising officer for juvenile welfare, Reverend (later Sir Robert) Hyde, Industry Was My Parish (1968), pp. 82-83.

45 Commission of Inquiry into Working Class Unrest: Report for the South East Area [PP, 1917-18, XIV], pp. 3-5.

46 Ministry of Munitions Papers 5/93/346/131 and 133.

47 History of the Ministry of Munitions, loc. cit., p. 47.

48 Ibid., pp. 47-49, and Hyde, Industry Was My Parish, op. cit., pp. 65-66. 
industrial unrest exploded in the middle of 1917 . Working-class solidarity was bound to be damaged by the methodology implicit in the supervisor's work. ${ }^{49}$ She kept individual records of employees in her care; she encouraged workers to perceive their problems on an individual basis and dealt with them accordingly. The price for this increased personal attention was that the shop-floor was encouraged to look on particular injustices as the product of individual circumstances - or even personal failing. In this way, the workers' collective right to present their own demands to management was weakened.

On several occasions clashes were reported between shop-stewards and welfare supervisors, each claiming to be the true representative of the workers' interests and each seeking to attract the loyalty of the new industrial recruits. ${ }^{50}$ From the point of view of the union organisers, it was implausible that welfare supervisors could claim to represent rank-and-file demands to management, while being employed for the purpose of maximising productivity and - implicitly - profits. The two roles were irreconcilable. The welfare supervisor - as described by the Women's Trade Union League Review in April 1917 - was "a paid official of anomalous position and divided interests". In April 1918 Woolwich Trades Council acknowledged that welfare supervisors had a useful role to play, but demanded that they be recruited from the shop-floor. ${ }^{51}$ The unions wished to re-assert labour control over the presentation of demands to management, while conceding that improvements in working conditions were desirable in themselves. If a management employee was allowed to usurp such work, the right of the labour movement to negotiate on behalf of its members was threatened and the shop-floor's right to determine working conditions was lost.

The main struggle between unions and welfare supervisors at local level was rooted in this question of control. The threat presented by welfare supervisors was, however, comparatively explicit. Also, their constant petty intrusions into the private lives of women munitions workers - ranging from personal dress to domiciliary arrangements - added fuel to the fire, and therefore added further rank-and-file support to those organisers who wanted to see welfare officers abolished. Supervisors were, however, the thin end of the wedge. Charged with implementing recommendations made by the HMWC and condoned by the Ministry, they bore the brunt of an attack on the rights of organised labour, which were implicitly threat-

49 Kozak, "Women Munitıon Workers", pp. 277-82.

${ }^{50}$ History of the Ministry of Munitions, loc. cit., p. 49.

51 Ibid. 
ened by the whole ideology underpinning the work of the Welfare and Health Department. Increased state intervention, backed by empirical scientific research, had more widespread consequences concerning changing patterns of social control which it was dangerous for the union movement to concede.

The research undertaken by such august bodies as the HMWC and the Medical Research Committee (forerunner of the better known Medical Research Council) ${ }^{52}$ was based, in principle, on theories of scientific management. Both committees spent time and energy promoting their findings concerning the effects of industrial conditions on the productive capacity of the worker. The authority their recommendations carried was based on its scientific validity; empirical research provided objective solutions. Yet such research started from the assumption that maximum productivity was the sole aim of industrial organisation - an assumption that the union movement had been calling to question for some time. Moreover, scientific "objectivity" in determining the "right" working conditions automatically precluded the worker deciding what these should be. His involvement rendered his view point biased. This attitude is discernable in Collis's barbed remarks about the "ill directed demands of labour" quoted above. It is also apparent in the Medical Research Committee's "Memorandum on Hours of Work in Relation to Output and Health", which went out of its way to establish medical evidence to prove that the subjective assessment of an individual's state of health was not necessarily scientifically valid.

Output, no less than health, depends on the right and economical use of the human machine [...]. bodily sensations are not a trustworthy guide to the true state of fatigue, which may be materially affecting output before the sensation of fatigue is plainly discernable. ${ }^{53}$

If workers were to retain any control over their life and labour, the implications behind this sort of theorising had to be opposed all down the line. In its purest form, scientific management could not be reconciled with free collective bargaining over working conditions. However, research into the problems of industrial fatigue had introduced new limits on the length of the working week; this eventually bore fruit in the Hours of Employment

52 The National Health Insurance Commission created the committee in the spring of 1916; extra public money was made available for medical research, see Treasury Papers $1 / 11915 / 7373 / 16$.

53 Memorandum on Hours of Work, p. 1. See also note 27 and HMWC, "Causes of Fatigue in Munition Work", Ministry of Munitions Papers 5/92/346/36. 
Bill in $1919 .^{54}$ On such and similar occasions scientific support was useful. Organised labour's attitude to its impact on social policy remained very undecided.

By the end of the war, employers in controlled establishments also resented the constant interference of the Ministry of Munitions in the process of industrial management. At factory level, directives and recommendations about working conditions were indistinguishable from the general plethora of regulations which poured out from the centre. All were concerned with imposing restrictions and all were resented for so doing. To all intents and purposes, control in the factories was removed from private hands for the duration of the war. Employers became managers, running their business on the government's behalf. Central direction, however, proved problematic and unpopular. Employers were not only told whom they could and whom they could not employ, but were pushed into allowing labour an increased say in questions of management, through the introduction of works committees and joint industrial councils. On the welfare front, after 1917 the welfare inspectorate bullied employers into conforming with an eternity of specifications about diet, washing facilities, overtime, tea breaks and physical education for juveniles. All demanded alte-ations in existing practices, all put up running costs because they necessitated an increase in non-productive staff. All major decisions concerning the management of labour - including compulsory official arbitration of industrial disputes - had to be referred to London.

This process produced delays and confusion; the multitude of interlocking rules and regulations governing industrial production were sometimes inoperable, occasionally contradictory. By the end of the war most employers were looking for a return to the pre-war relationship between state and industry. It had rapidly become clear that the imposition of central control exacerbated more problems than it solved. Faith in scientific management was making the system too inflexible; those operating locally found much state intervention unwarranted and positively destructive of good labour relations. In the ship-building and

54 Government acceptance of the 48-hour week was probably due less to the recommendations of the Medical Research Committee than to the need to keep in line with the International Labour Convention's agreement of 1919, and to respond to persistent pressure from organised labour for legislation on this point (the proposal originally came from the Provisional Joint Committee of the National Industrial Conference). However, restrictions on hours of work introduced in 1916 were justified by reference to American and British research into the effects of industrial fatigue. The point is that such research could be used to vindicate concessions made to organised labour on such questions, while simultaneously denying that workers' demands were, in themselves, legitimate. 
engineering trades, where dilution had brought welfare provision under the direct scrutiny of Dr Collis's inspectors, methods and principles of scientific management went strongly against the grain. Such industries had, in pre-war days, been built up as family firms and run accordingly. Acknowledging the primacy of scientific investigation in determining modes of management implied a challenge to the right of such employers to supervise their business as they saw fit. Many employers had no objection to scientific investigation producing advice for their consideration, but objected strongly when this developed into a justification for laying down rules which had to be obeyed. If such strategies had proved effective in counteracting labour unrest, this direction might have been tolerable. This was not the case; the latter years of the war saw increasing industrial unrest. As Gerry Rubin has pointed out in his work on munition tribunals, by the time of the Armistice, many employers were convinced that the wartime experiment had been more harmful than beneficial to their affairs.

For the employers, decontrol was all. Their factories effectively nationalised during the war, they were in no mood to consider anything but a return to laissez-faire, and if this, too, entailed abandoning legislative support, for the enforcement of discipline, then this was a small price to pay to regain freedom from State control. ${ }^{55}$

Events certainly indicated that employers were keen to re-assert their autonomy in the determination of working conditions. In the summer of 1918 the Industrial Welfare Society was founded. It was created by the Reverend Hyde, who had been in charge of promoting juvenile welfare when Rowntree had been director of the Welfare Division, and who had resigned in protest at the bureaucratic methods introduced by Collis in 1917. The society was funded exclusively by employers and employers' organisations - notably the Shipbuilding Employers Federation. Hyde took full advantage of the contacts his job provided. The dedicated aim of the Industrial Welfare Society was to encourage the voluntary provision of improved amenities and, until the winding up of the Ministry of Munitions the following year, it worked in direct competition with Collis's welfare inspectors. The society was remarkably successful; after the war it secured royal patronage and became highly respected. ${ }^{56}$ It was, indeed, the forerunner of the present-day Institute of Personnel Management. Clearly many employers condoned the aims and objectives of industrial welfare, even if they resented state intervention in its implementation. It is inter-

55 Rubin, "The Origins of Industrial Tribunals", loc. cit., p. 163.

56 The foundation and activities of the society are described in Hyde, Industry Was My Parish, ch. 8 . 
esting to note that the Industrial Welfare Society was clearly determined to re-assert the total authority of the employer in the field of industrial welfare. In 1920, its refusal to co-operate with the newly established professional associaion for welfare supervisors in encouraging the growth of welfare work in industry appears to have given the lie to its philanthropic intentions. ${ }^{57}$

By November 1918 the trend towards "home rule for industry" was well established. During 1919 private concerns continued to push for the withdrawal of state controls - both in the House of Commons and in Whitehall as well as in chambers of commerce all round the country. Continued state direction of production in peacetime assumed that the interests of private enterprise were identical to those of the state and therefore could be best served through the mediation of professional expertise operating from inside central government. Industrial expansion was vital if Britain was to win the battle for international markets in the post-war world; such expansion could only be achieved through the unmitigated activities of private enterprise. Such attitudes were not peculiar to Britain; all over Europe in 1919 there was a resurgence of what R. H. Tawney called "the last spasm of nineteenth century individualism". ${ }^{58}$

Not surprisingly, this mood was also reflected inside most government ministries. The Ministry of Munitions had proved inordinately incompetent in handling its own affairs; as early as June 1917 the Treasury was convinced that - as a business venture - it was a total failure. ${ }^{59}$ Not surprisingly, its record in this respect made private enterprise somewhat sceptical of the efficacy of the methods it propagated. Once demobilisation was complete and continued need for industrial controls - of raw materials as well as labour - passed, the Ministry was wound up. Its remaining responsibilities in the field of industrial welfare reverted to the two departments whose work it had long duplicated - the Home Office and the Ministry of Labour. Neither department had the inclination - and the latter department certainly had not got the resources - to expand their

57 The Ministry of Labour's efforts to arbitrate in the dispute are documented in Ministry of Labour Papers 2/741/T6402/1920, PRO.

58 R. H. Tawney, "The Abolition of Economic Controls, 1918-21 (1941)", in History and Society, ed. by J. M. Winter (London, 1978), pp. 154-55. For further examination of the withdrawal of state controls, see P. Barton Johnson, Land Fit for Heroes (1968), ch 10, 13 and 14. See also M. B. Hammond, British Labour Conditions and Legislation During the War (London, 1919), pp. 243-63.

59 See First and Second Reports of the Select Committee on National Expenditure, 1917, Treasury Papers 172/653, and the Auditor General's Appropriation Account for 1916-17. Treasury dissatisfaction with the Ministry's financial competence was still being voiced the following spring, see minute 18 April 1918, Treasury Papers 172/832. 
work in this field in order to formulate new programmes of industrial welfare. ${ }^{60}$ Instead, it was tacitly acknowledged that welfare at the workplace was best determined by negotiation between employers and unions, through joint industrial councils. Although, in practice, these councils proved singularly uninterested in debating questions of this nature, in theory at least administrators appeared to concede that the whole area was ultimately the business of industry itself. Also, in purely practical terms, the very complexity of welfare recommendations made them very difficult to impose from the centre; labour management was most effective if determined and implemented at factory level.

Industrial decontrol and the abolition of government sanctions over labour welfare and management did not spell a return to the status quo ante. It would be a mistake to conclude that official interest in and promotion of industrial welfare disappeared with the Ministry of Munitions. In the Ministry of Labour, special sections were created to deal with the problems of women and juveniles in industry. Although the latter spent most of its energies in demarcation disputes with the Board of Education, the former continued the work the Ministry of Munitions had begun by taking an active interest in working women. It did, however, reverse previous policy. During the war, the main objective had been to encourage women to take up industrial employment and to ensure that welfare could be used as a means of enforcing industrial discipline. By the early 1920's, by contrast, official intervention was designed to get women out of insured employment and back into domestic service. ${ }^{61}$ Although providing an interesting variant in official efforts to regulate the labour market, such activity could hardly be incorporated under the label "welfare". However, the Ministry did establish and main tain close contacts with the Industrial Welfare Society and went out of its way to promote voluntary improvement of welfare amenities on the factory floor. ${ }^{62}$

The main impact of wartime on post-war social policy concerned the development of government research, designed to benefit private industry. On the one hand, the creation of the Department of Scientific and Industrial Research was a clear demonstration of the commitment of public money to technical and scientific innovation which would stimulate

60 R. Lowe, "The Ministry of Labour: A Graveyard of Social Reform?", in: Public Administration, LII (1974).

61 The inequitable treatment of women - especially married women - under the unemployment-insurance scheme gave rise to a number of deputations of protest. For example, see report of the deputation from the National Union of General Workers (Women's Section), 18 July 1921, Ministry of Pensions and National Insurance Papers $7 / 54$, PRO.

62 Ministry of Labour Papers 2/741/CS204/1920. 
new industry. On the other hand, the above-mentioned organisation, the Medical Research Council and the Home Office set up the Industrial Fatigue Research Board, which continued the type of scientific research originally pioneered by the HMWC. In 1920, this board changed its name to the Industrial Health Research Board and - like the HMWC before it generated a series of publications designed to promote scientific management in industry. Once again, welfare provision was correlated with its impact on productivity. Studies made included the comparative effect of rest pauses, the impact of different hours of work, fatigue and efficiency in the iron and steel industry, a comparison of shift systems in the glass trade ${ }^{63}$ One title deserves special note: "A study of Personal Qualities in Accident Proneness and Proficiency". The process of individualising welfare, born in the work of welfare supervisors, eventually generated the type of scientific investigation which founded the whole industrial-psychology movement.

However, although the new methods of using scientific analysis to legitimate improvements in industrial welfare continued in the post-war world, the role of government in directing their introduction did not. Economic and industrial opinion alike wanted to see all commercial enterprise returned to private hands; methods of management reverted to the control of the individual employer. How far the literature referred to in the previous paragraph influenced management in the inter-war period is open to conjecture. It seems likely that its influence was marginal, except in those areas and in those sectors which continued to suffer labour shortages. The onset of mass unemployment in the 1920's restricted the need for private welfare - which had developed as a system designed to control labour when it was scarce. Welfare was designed to stimulate productivity and to minimise the possibility of working-class opposition to this process. Once labour became plentiful and cheap, market forces created pressures to encourage conformity and re-asserted traditional managerial controls over the industrial workforce. This general picture conforms to the pattern described by Huw Beynon in his book Working for Ford, ${ }^{64}$ which demonstrates how the use of different techniques of scientific management frequently correlated with periods of acute labour shortage.

This analysis helps explain the regional variation in the application of industrial welfare in Britain during the inter-war period. It also helps us to understand why government remained basically uninterested in the enforcement of minimum requirements, even though it continued to finance

${ }^{63}$ Lists of such publications appear on the covers of the Ministry of Labour Gazette by the end of the decade.

${ }^{64}$ H. Beynon, Working for Ford (London, 1973). 
research to determine what these requirements should be. It was not until the outbreak of the Second World War that official interest was revived. However, variation in policy over this matter is clearly explained less by whether the nation was at peace or war than by variance in the numbers of unemployed.

\section{III}

State intervention in industrial welfare was born of a crisis which made questions of productivity, industrial relations and labour management of direct concern to national survival. During the war, acute labour shortages prevented normal pressures of the market-place helping employers discipline their workforce; in consequence industrial-welfare strategies underwent a substantial change. Initially, matters concerning working arrangements and conditions were of no great public concern; the individual employer adopted techniques to suit his particular purpose. During the war, private practice became subject to public scrutiny. It was vital to ensure the full and effective use of the "human machine"; such matters could not be left to the private whim of the employer or the demands of trade unions. The capacity of the worker was established by scientific investigation; medical evidence began to assume the status of the law itself in determining the nature and extent of private welfare provision. These developments did not spring from an increased altruistic desire to promote social justice, or as a government response to the demands of organised labour. Rowntree's gentlemanly brand of philanthropic concern over industrial welfare was very different in kind from the rational, "scientific" approach of his colleagues - hence the internal disagreements and his eventual resignation. Welfare became a part of the new science of labour management; its twin objects were to promote productivity and reduce potential militancy from the union movement. Academic research gave it the aura of professional respectability necessary to convince a wider public of the importance of industrial welfare to the general good of the community.

In this way, scientific management legitimated an authoritarian approach to problems of industrial discipline. While maintaining an aura of impartiality, it produced solutions that appeared to offer advantages to both sides of industry. For the employers, it offered techniques designed to maximise productivity. For the workforce, it produced justifications for improving not only hours and conditions, but for better housing, transport and leisure facilities. As promoted by the Ministry of Munitions, growth of industrial welfare seemed highly desirable. This appearance of objective 
impartiality was, however, fallacious. As techniques involved in scientific management gained ground, so the worker became increasingly seen - in welfare terms - as a series of functions in the process of industrial production. Labour was a vital component in maximising industrial efficiency. The needs of labour became subordinate to the needs of the production process. Although, it could be argued, the end product was the same, this ordering of priorities pre-empted the right of workers even to contribute far less control - decisions over what improvements should be made, even if this was being done ostensibly for their benefit. Private industrial welfare had been promoted by a Ministry which had acted as an employer and it was to the employer that the system gave advantages.

The experience of the First World War showed how industrial welfare increased the reliance of the worker on his employer. The more benefits management could provide, the more they could withdraw; the system added a new dimension on the enforcement of industrial discipline. At the same time, the attraction of trade unionism diminished. The work of the welfare supervisor was designed to minimise the attractions of union organisation. Apart from providing an alternative avenue of communication with management in order to promote the redress of grievances, the very process of encouraging workers to see these grievances as individual problems rather than collective complaints was potentially damaging to working-class solidarity. Also, the principle of scientific objectivity in determining standards weakened the unions' right to bargain over pay and conditions. The sole objective was increased industrial efficiency; intervention by organised labour was, by definition, counterproductive, because union aims were not dedicated solely to this goal.

This study reinforces the analysis made by James Hinton, that welfare activities of government were designed to increase industrial discipline and ensure that organised labour should present no threat to the established social order. ${ }^{65}$ Industrial welfare was introduced to supplement more overt forms of labour regulation during the war. In promoting private welfare, no secret was made of the fact that the main object of the exercise was to raise industrial productivity. It is not possible to interpret this intervention simply as a short-lived and somehow uncharacteristic response at a time of unprecedented crisis. When the war was over, government continued to sponsor exactly the same research as had been been undertaken during the war, continued to publish findings of quasi-medical investigations pertaining to management questions and continued to allow expenditure on private-welfare provision to be deducted against tax. A glance at the

${ }^{65}$ Hinton, The First Shop Stewards' Movement, ch. 1. 
subsequent development of industrial welfare since the First World War seems to underline the point. It has expanded enormously and is clearly used to supplement other work incentives by providing a range of benefits for long service and extra rewards on promotion. Since the Second World War, the provision of company cars, housing allowances, private pension schemes and so on, all have been increasingly incorporated into a system which benefits those who work hard and conform to the expectations of their employers. ${ }^{66}$ This form of welfare has nothing to do with helping those in need. The examination of its origins and growth during the First World War, however, makes its subsequent development appear only too logical.

The political relationship between state and employers over questions concerning the government of private industry is not easily analysed. Ostensibly allied by a common commitment to increasing productivity, the interests of industrialists and state bureaucracy divided over the question of managerial control. Wartime central direction of industrial production had not been an unqualified success. Civil servants and employers both supported the move to "home rule for industry" after the war: but the former retained an interest in determining the methods of managing men, materials, industrial relations. This interest was not direct, rather it was vested in the implicit belief that methods and strategies approved by the state - in spite of the political climate - still provided the basis for correct solutions to most industrial problems. The hallmark of the scientific approach - impartial objectivity - fitted in nicely with the state's proclaimed stance in its dealings with industry. However, the recommendations of scientific management incorporated re-organisation of management structures as well as labour processes. Many sectors of British industry were owned by a complex number of rival firms; it was unlikely that employers in such sectors would willingly carry scientific logic to its obvious conclusions and damn themselves to extinction.

Hence, within the realm of labour management many employers proved suspicious of new methods. Although easily condemned by both contemporaries and some historians as reactionary and backward, this innate conservatism was, in itself, evidence of a real conflict of interest. This type of criticism, moreover, supposes that the scientific methods advocated by government agencies provided the only path forward to industrial expansion, wherein lay national prosperity and general well-being. Leaving aside the major debate as to the possibility of a plausible consensus on such

${ }^{66}$ See R. M. Titmuss, "Benefits in Kind", in Income Distribution and Social Change (London, 1962). 
matters, it is worth pointing out that - within the discussions over industrial welfare - scientific analysis was flawed within its own terms. Given ideal and uniform working conditions, the "human machine" would not necessarily conform to expectations. The investigator not only neglected wide variance in physical attributes, but also the fact that the industrial labour-force was something more than a series of functions housed in a large number of units. The development of scientific methods gave rise to a plethora of disciplines concerned with labour regulation and management. It thereby generated a new form of authority in determining how industrial enterprise should be run; it legitimated professional surveillance and interest in industrial performance. The general failure of scientific management lay in the inability of its practitioners to appreciate or predict the degree of hostility and political conflict its introduction would generate from those industries it was most concerned to help. 